\title{
Konservasi Berbasis Kearifan Lokal di Situs Benteng Puteri Hijau, Deli Serdang, Sumatera Utara
}

\author{
Stanov Purnawibowo \\ Balai Arkeologi Medan \\ Email: anop_siva@yahoo.com
}

\begin{abstract}
Abstrak: Penanaman pohon pisang barangan (Musa paradisiaca sapientum L) pada benteng tanah yang dinyatakan sebagai tinggalan arkeologis di situs Benteng Puteri Hijau merupakan suatu wujud kearifan lokal dalam aktivitas konservasi material. Penelitian ini mencoba mencari formulasi bentuk kearifan lokal pada konservasi benteng tanah di situs Benteng Puteri Hijau. Penelitian tersebut dilakukan dengan pengamatan lapangan keberadaan tanaman pisang di gundukan tanah serta mewawancarai pemiliknya, kemudian mengelaborasinya dengan kepustakaan yang berkaitan dengan konservasi tanah. Penelitian ini dimaksudkan untuk mencari bentuk konservasi berbasis kearifan lokal yang bertujuan untuk menambah ragam jenis bentuk konservasi material terhadap tinggalan arkeologi di Indonesia secara umum.
\end{abstract}

Kata kunci: benteng tanah, konservasi, pohon pisang barangan, erosi, kearifan lokal

Abstracts: Using trees of 'barangan' banana (Musa paradisiaca sapientum L) on earth fort - it is considered as archaeological remains - found at Puteri Hijau Fort Site is a form of local wisdom in conservation activities. This study attempts to formulate the pattern of local wisdom on conservation of earth fort in Puteri Hijau Fort Site. The study was conducted by field observations where the barangan was planted on earth fort and interviewing its owner, then elaborating with literatures related to earth conservation. This study is intended to find the pattern of conservation based on local wisdom that aims to increase the range of types of material to the pattern of the conservation of archaeological remains as general in Indonesia.

Key words: earth fort, conservation, barangan's tree, erotion, local wisdom

\section{Pendahuluan}

\section{Latar belakang}

Konservasi merupakan salah satu upaya dalam pelestarian suatu cagar budaya ataupun tinggalan arkeologis yang belum ditetapkan sebagai cagar budaya. Salah satunya adalah konservasi material tinggalan arkeologis dengan memanfaatkan kearifan lokal masyarakat yang berada di sekitar tinggalan arkeologis. Konservasi material dilakukan agar tinggalan arkeologis tersebut dapat dilestarikan dan terhindar dari kerusakan, atau meminimalisir kerusakan tinggalan tersebut. Upaya konservasi material dapat dikatakan sebagai salah satu tindakan pelindungan. Berdasarkan uraian tersebut, konservasi material merupakan upaya pelindungan terhadap objek material dari masa lalu yang dilakukan agar benda-benda tersebut dapat dilestarikan.

Secara umum pada acara Workshop Konservasi Cagar Budaya Berbasis Kearifan Tradisional yang diadakan oleh Balai Koneservasi Borobudur pada tanggal 11 hingga 15 Agustus 2014 di Yogyakarta, konservasi material cagar budaya dilakukan terhadap tinggalan arkeologis berbahan kayu, logam, batu, tanah liat, keramik, bata, bambu, manik-manik, lontar, dan lain sebaginya. Adapun upaya konservasi material terhadap tinggalan arkeologis berbentuk benteng tanah yang merupakan satu kesatuan utuh dengan bentanglahannya (landscape), serta memiliki cakupan luas belum dikemukakan. Salah satu bentuk tinggalan arkeologis berbentuk benteng tanah adalah situs Benteng Puteri Hijau.

Situs Benteng Puteri Hijau merupakan tinggalan masa lalu hasil modifikasi bentang lahan yang dijadikan sebagai lokasi permukiman. Modifikasi tersebut tampak pada sentuhan artifisial di beberapa bagian dinding sungai yang mengelilingi situs ini. Sentuhan artifisial tersebut berupa pembentukan benteng tanah yang dilakukan dengan cara meninggikan bagian tebing sungai menggunakan tanah di bagian luarnya, sehingga tanah di bagian luarnya membentuk cekungan. Cekungan tersebut selanjutnya difungsikan sebagai jagang/parit benteng.

Situs ini berada di bagian hulu daerah aliran Sungai Deli yang pada bagian hilirnya mengalir di Kota Medan. Gundukan tanah di lokasi tersebut sekilas akan tampak seperti tebing sungai yang memiliki teras. Gundukan tanah yang tampak di beberapa lokasi (lihat Gambar 2) berbatasan langsung dengan teras dan dataran banjir 


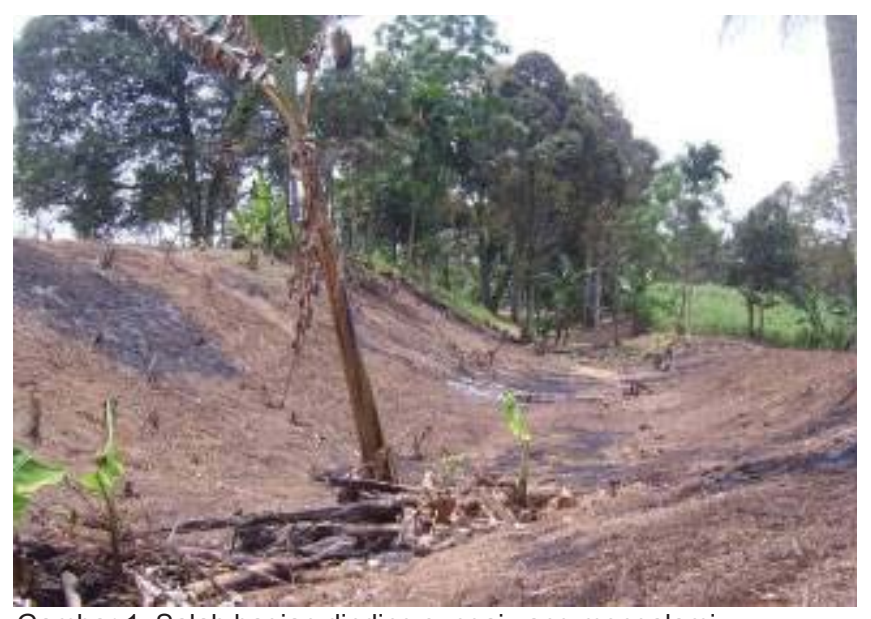

Gambar 1. Salah bagian dinding sungai yang mengalami pengerjaan artifisial dibentuk menjadi benteng tanah dan parit (sumber: Tim Penelitian, 2009)

Sungai Deli. Pada benteng tanah tampak rimbunan pohon pisang barangan (Musa paradisiaca sapientum L) dan jenis tanaman lainnya yang sengaja ditanam oleh penduduk di sepanjang benteng tanah tersebut. Adapun status situs tersebut, saat ini sedang dalam proses akhir untuk ditetapkan sebagai cagar budaya oleh Pemerintah Kabupaten Deli Serdang, Provinsi Sumatera Utara.

Berkenaan dengan konservasi material berbasis kearifan lokal di situs tersebut, tampak adanya indikasi keterkaitan antara upaya penanaman pohon pisang barangan dengan sistem tumpang sari oleh masyarakat di sekitar situs Benteng Puteri Hijau dengan upaya konservasi terhadap struktur benteng tanah tersebut. Penanaman pisang barangan dengan cara dicampur tanaman lain, serta pembiaran struktur benteng tanah tertutup oleh tanaman rerumputan dan ilalang sengaja dilakukan masyarakat agar benteng tanah tidak tererosi.

Erosi secara umum adalah peristiwa pengikisan padatan (sedimen, tanah, batuan, dan partikel lainnya) akibat transportasi angin, air atau es, karakteristik hujan, gerakan pada tanah dan material lain di bawah pengaruh gravitasi, atau oleh makhluk hidup semisal hewan yang membuat lubang, dalam hal ini disebut bio-erosi. Erosi sebenarnya merupakan proses alami yang mudah dikenali, namun di kebanyakan tempat kejadian ini diperparah oleh aktivitas manusia dalam tata guna lahan yang buruk, penggundulan hutan, kegiatan pertambangan, teknik perkebunan dan perladangan yang tidak sesuai dengan kondisi tanahnya, kegiatan konstruksi atau pembangunan yang tidak tertata dengan baik dan pembangunan jalan (Sumarno, 2013: 3).

Adapun konsep konservasi berbasis kearifan lokal secara umum dapat dimaknai sebagai suatu sistem yang mengintegrasikan antara pengetahuan, kelembagaan, serta praktik pengelolaan sumber daya yang ada pada masyarakat dalam menyusun dan menata materi sebagai suatu respon terhadap kondisi lingkungan dan daya antisipatif terhadap perubahan kondisi lingkungan. Konteks lingkungan tersebut berupa lingkungan fisik, lingkungan budaya, ataupun lingkungan sosialnya (Koestoro, 2010).

\section{Permasalahan}

Berdasarkan uraian di atas, permasalahan yang akan ditetapkan adalah "Bagaimana relasi antara penanaman pisang barangan dan tanaman lainnya pada benteng tanah dengan upaya konservasi material struktur benteng tanah di situs Benteng Puteri Hijau?". Untuk menyelesaikan permasalahan tersebut, pembahasan yang dilakukan dalam penelitian ini akan dibatasi pada relasi antara aktivitas penanaman pisang barangan (Musa paradisiaca sapientum L) oleh warga di lokasi situs benteng tanah dengan upaya konservasi benteng tanahnya.

\section{Maksud dan tujuan}

Penelitian ini dimaksudkan untuk mengetahui adanya salah satu bentuk kearifan lokal di sekitar situs Benteng Puteri Hijau berupa relasi antara penanaman pohon pisang barangan di struktur benteng tanah dengan upaya konservasi benteng tanahnya. Adapun tujuannya adalah untuk mengetahui jenis konservasi material terhadap benteng tanah yang berbasis kearifan lokal di situs Benteng Puteri Hijau.

\section{Kerangka berpikir}

Biornstad (1990:72) mengatakan bahwa perlindungan suatu tinggalan masa lalu berkaitan erat dengan lingkungan dan hubungannya dengan sejarah dan masyarakat kontemporer. Secara implisit konsep tersebut dapat dimaknai sebagai suatu tinggalan masa lalu yang bukan lagi milik masyarakat masa lalu dan sudah tidak ada lagi yang melanjutkan, mengubah penggunaan dan pemaknaannya. Tinggalan masa lalu adalah milik masyarakat masa sekarang, dan seiring waktu berjalan 
masyarakat tersebut menjelma menjadi masyarakat masa lalu di masa mendatang, dan kemudian akan meninggalkan jejak fisik dan makna pada tinggalan tersebut, selanjutnya tinggalan tersebut oleh generasi penerus mereka dianggap sebagai warisan budayanya, dan begitu seterusnya.

Hal inilah yang selanjutnya dapat diterjemahkan: segala aspek berkenaan dengan keberlangsungan tinggalan arkeologi tersebut diserahkan sepenuhnya kepada masyarakat sekarang yang berinteraksi langsung dengan tinggalan arkeologi tersebut, salah satunya adalah aspek konservasi materialnya. Berdasarkan hasil pemaknaan dan pengembangan konsep Biornstad tersebut, penelitian sederhana ini akan mencoba untuk mendapatkan formulasi bentuk dari peran masyarakat sekarang dalam menjaga dan melindungi tinggalan masa lalu yang ada di sekitarnya melalui konsep dan pengetahuan masyarakat tersebut.

\section{Tinjauan pustaka}

Penelitian berkenaan dengan keberadaan Benteng Puteri Hijau (BPH) telah dilakukan oleh BPCB Aceh Besar bersama Balai Arkeologi Medan tahun 2008 yang dilakukan di dalam kawasan BPH dan menghasilkan beberapa data arkeologi dari masa prasejarah hingga kolonial. Pada tahun 2009 dilakukan penelitian interdisiplin ilmu yang melibatkan disiplin ilmu arkeologi, geologi, antropologi dan sosiologi, sejarah, dan menejemen konflik sebagai bentuk penelitian CRM (Cultural Resources Management) dan penyelamatan BPH dari perluasan permukiman yang akan dilakukan di lokasi tersebut. Pada tahun 2011, Taufiqurrahman melakukan penelitian dengan observasi lansekap dan pengumpulan deposit arkeologis yang meliputi daerah BPH dan di sekitarnya. Kajiannya menghasilkan aspek pemanfaatan lingkungan untuk benteng tanah sebagai permukiman dan aktivitas pengaturan lalu lintas untuk permukiman di lokasi benteng (Setiawan, 2011: 77).

Kajian konservasi tanah dan jenis-jenis konservasi tanah secara umum telah dilakukan oleh Sumarno (2013) dari Universitas Brawijaya. Adapun untuk pengetahuan mengenai kondisi tanah dan jenis konservasi tanah yang cocok di sekitar daerah Kabupaten Deli Serdang dilakukan oleh Ai Dariah, Enggis Tuherkih, Achmad Rachman (2007) dari Balai Penelitian Tanah Bogor. Kajian ilmiah mengenai tata cara penanaman dan tanaman pisang barangan dilakukan oleh Balai Pengkajian Teknologi Pertanian Sumatera Utara (2008) dan Fransiska Natalina tahun 2009.

\section{Cara penelitian}

Perolehan data dilakukan dengan dua cara. Pertama adalah melakukan pengamatan di lapangan dengan mencermati keberadaan kebun pisang barangan milik warga yang ditanam di lokasi benteng tanah, kemudian mengadakan wawancara terhadap pemilik kebun pisang. Aktivitas ini menghasilkan data primer yang dilakukan pada tahun 2008 dan 2009. Kedua adalah dengan menelusuri data kepustakaan yang berkaitan dengan situs Benteng Puteri Hijau, pisang barangan, dan konservasi tanah. Aktivitas ini menghasilkan data sekunder. Selanjutnya fakta-fakta yang didapat di lapangan dielaborasikan dengan hasil kajian pustaka, untuk kemudian dipakai dalam menjawab permasalahan yang ditetapkan dalam penelitian ini. Hasil kajiannya berupa generalisasi berkenaan dengan relasi antara aktivitas penanaman pisang barangan pada struktur benteng tanah dengan konservasi struktur benteng tanah di situs Benteng Puteri Hijau.

\section{Benteng Puteri Hijau}

\section{Tinggalan arkeologis}

Benteng Putri Hijau (BPH) terletak di sebuah kawasan dengan morfologi bentanglahan yang relatif datar berada di bagian atas lembah Sungai Deli. Secara astronomis situs ini terletak pada batas selatan di $\mathrm{N} 3^{\circ}$ 28.630' E $98^{\circ} 40.338^{\prime}$ hingga paling utara di N $3^{\circ} 29.693^{\prime}$ E 9840.443', memanjang utara-selatan di tebing barat Sungai Deli, yang mengalir ke arah selatan. Adapun batas bagian barat berada di N $3^{\circ} 28.830^{\prime} \mathrm{E} 98^{\circ} 40.521^{\prime}$ dan paling timur berada N $3^{\circ} 28.913$ ' E 98 40.521'. Secara administrasi situs ini terletak di Desa Deli Tua Kampung, Kecamatan Namorambe, Kabupaten Deli Serdang, Provinsi Sumatera Utara (Tim Penelitian, 2009).

Berdasarkan hasil penelitian tahun 2009, di lokasi situs tersebut terdapat sisa artifisial manusia masa lalu berupa benteng tanah, parit benteng, fragmen keramik, fragmen gerabah, koin deureubam, sisa alat pertanian. Adapun sisa struktur benteng tanah yang masih tersisa berada di sisi bagian utara situs ini, sedangkan di bagian tengah dan selatan situs 
ini struktur benteng tanah dan parit benteng hanya tersisa sedikit saja, yaitu struktur yang berada di tebing sungai. Survei dan ekskavasi di situs Benteng Puteri Hijau tahun 2009 dilakukan pada 5 (lima) lokasi yang dianggap mewakili situs tersebut. Adapun perkiraan sementara luasan situs tersebut sekitar 50 Ha. Pada kelima lokasi tersebut, total dibuka 23 buah kotak ekskavasi (lihat Gambar 2).

Benteng Puteri Hijau dapat dikatakan sebagai sebuah situs yang di dalamnya terdapat sisa benteng tanah. Masa hunian di situs Benteng Puteri Hijau diindikasikan pada kurun waktu abad ke-13 hingga abad ke-17 Masehi. Sisa tembok atau dinding tanah yang mengelilingi areal masih tampak, begitu pula keberadaan parit keliling di bagian tenggara. Berkaitan dengan pertapakan yang dikelilingi bagian lahan yang masih rendah, pemanfaatan tebing sebagai bagian perbentengan itu sendiri masih tampak dan sebagian berkenaan dengan bantaran Sungai Deli. Penelitian yang dilakukan tahun 2009 menyimpulkan bahwa Benteng Puteri Hijau bukan merupakan bentukan alam, tetapi dibuat oleh manusia. Benteng di Sektor II tanahnya diambil dari sebelah tenggara (di sekitar kotak-1) yang digali memanjang timur laut -- barat daya. Benteng di Sektor III tanahnya diambil dari sebelah timur (di sekitar kotak-3) yang digali memanjang utara-selatan. Benteng di Sektor IV tanahnya diambil dari sebelah selatan (di sekitar kotak-2) yang digali memanjang timur-barat. Berdasarkan atas pengamatan lapangan dan analisis strata tanah pada beberapa kotak ekskavasi di Situs Benteng Puteri Hijau membuktikan bahwa benteng tersebut dibuat oleh manusia dengan memanfaatkan lahan yang tersedia. Hal ini juga terbukti bahwa dataran-dataran di dalam benteng lebih tinggi dari dataran-dataran yang berada di luar benteng (Tim Penelitian, 2009: 83 -- 85).

Data artefaktual yang berhasil didapat dari situs ini terdiri dari berbagai macam ragam dan jenis. Ditinjau dari aspek formal/bentuk, jenis artefak lepas yang dijumpai berupa tembikar, keramik, logam, serta alat batu. Jenis artefak berbahan tanah yang dibakar seperti tembikar dan keramik ditemukan dalam kondisi fragmentaris, baik yang berasal dari permukaan tanah maupun hasil ekskavasi. Jenis artefak ini sebagian besar merupakan wadah yang umum dipakai dalam aktivitas sehari-hari, seperti: mangkok, kendi, guci, tempayan, pasu, piring, serta

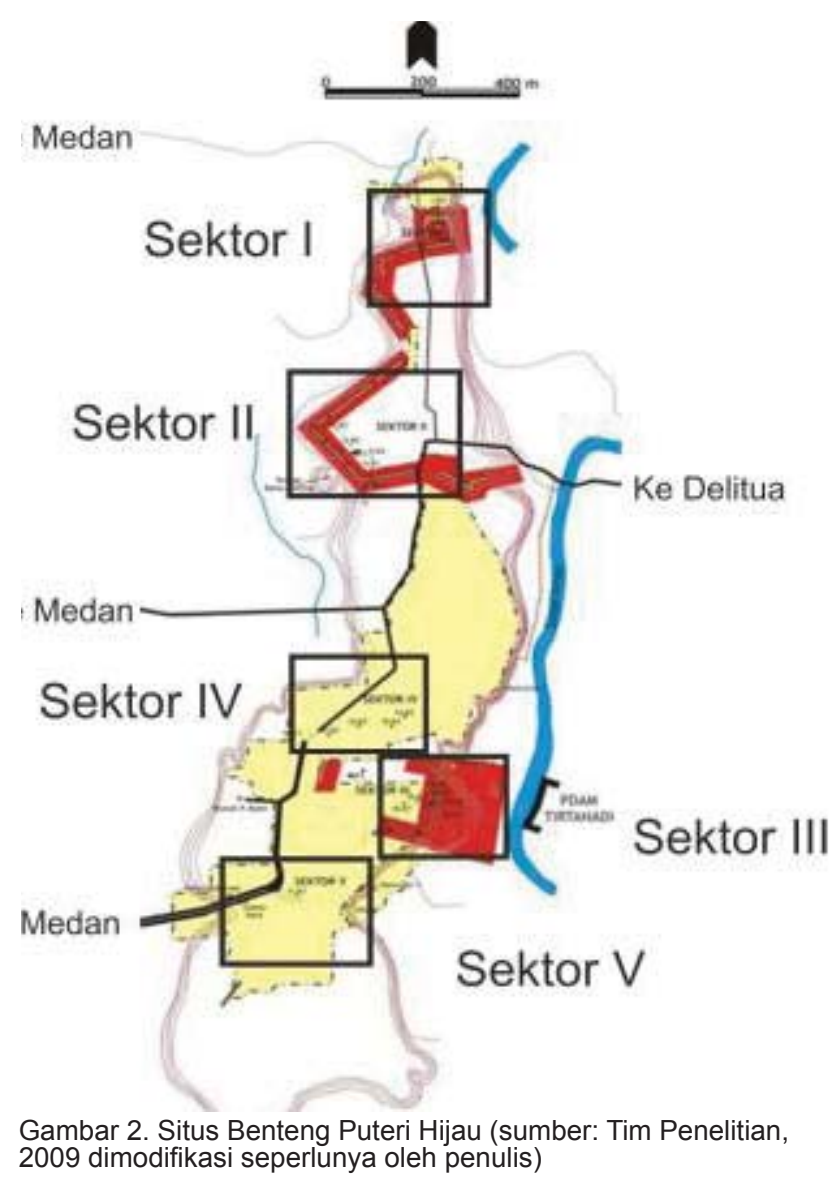

teko. Adapun artefak berbahan logam yang ditemukan di sekitar situs berupa uang logam berbahan emas, selongsong peluru, peluru bulat, alat berbahan logam yang diidentifikasi sebagai grathul (Jawa, alat pertanian untuk membersihkan tanaman dari gulma), serta kerak besi seberat 7 gram yang ditemukan di kebun coklat atau kakao (Theobroma cacao L.) milik warga pada penelitian tahun 2008. Adapun artefak alat batu sumatralith berbahan batuan beku juga ditemukan berjumlah 3 buah pada penelitian tahun 2008 .

Ditinjau dari aspek temporal, data artefaktual yang ditemukan berasal dari berbagai rentang masa. Jenis artefak sumatralith berasal dari masa pengaruh budaya prasejarah yang diidentifikasi pernah ada di situs tersebut. Adapun jenis artefak fragmen tembikar dan keramik diidentifikasi berasal dari rentang masa abad ke-13 -- ke-18 Masehi. Artefak logam berupa: mata uang emas diduga berasal dari Aceh abad ke17 Masehi; selongsong peluru berasal dari masa abad ke-20 Masehi yang digunakan untuk senapan serbu laras panjang jenis CIPS FNC, Kaliber (KL) 5,56 mm buatan Belgia; proyektil bulat berbahan logam timah hitam berasal dari masa abad ke-15 -- ke-20 Masehi; 
serta grathul (sejenis alat pertanian seperti cangkul kecil) dari masa saat daerah tersebut dijadikan sebagai lokasi perkebunan tembakau pada akhir abad ke19 hingga awal abad ke-20 Masehi (BP3, 2008; Tim Peneliti, 2009).

Berkenaan dengan aspek spasial temuan artefaknya, diidentifikasi berasal dari luar daerah situs. Hal tersebut diketahui dari hasil identifikasi dan analisa penelitian di lokasi situs belum ditemukan jejak fakta dari masa lalu yang mengindikasikan sebagai tempat produksi berbagai artefak tersebut. Adapun temuan fragmen keramik berasal dari Cina dan Thailand. Mata uang emas berasal dari Aceh, serta selongsong peluru buatan Belgia. Sedangkan alat batu, pelor timah hitam, kerak besi dan grathul belum dapat diketahui secara pasti (BP3, 2008).

Masyarakat masa lalu di situs Benteng Puteri Hijau memanfaatkan lereng sungai yang relatif terjal sebagai benteng tanah untuk melindungi permukiman mereka dari berbagai ancaman, baik itu ancaman bencana alam maupun serangan lawan. Pemanfaatan topografi di sekitar situs tersebut berupa penambahan tanah sehigga struktur tanah di bagian yang dekat dengan lereng sungai menjadi tinggi hingga membentuk struktur benteng tanah. Peninggian lahan tersebut dilakukan dengan mengambil tanah dari lokasi dalam areal benteng. Hal itu dibuktikan dengan keberadaan lapisan stratigrafi pada benteng tanah yang serupa jenisnya dengan lapisan tanah yang ada di dalam areal situs benteng tanah (Tim Penelitian, 2009).

\section{Pohon pisang barangan di situs Benteng Puteri}

Hijau

Pisang barangan (Musa paradisiaca sapientum L) merupakan tanaman pisang spesifik berasal dari Provinsi Sumatera Utara. Tanaman pisang ini memiliki beberapa keunggulan dibandingkan jenis pisang lainnya. Beberapa keunggulan tersebut terletak pada ketebalan dan kekuatan daun, bidang penampang daun yang lebih luas, serta rasa daging buahnya lebih manis. Selain dimanfaatkan buahnya, bagian bunga dan bonggolnya biasanya dimanfaatkan sebagai sayur, manisan, acar, dan lalapan oleh masyarakat di Sumatera Utara. Adapun daunnya hingga saat ini masih dimanfaatkan sebagai alat pembungkus. Pisang barangan termasuk varietas unggulan dari Sumatera Utara yang telah ditetapkan oleh SK Menteri Pertanian No. 38/ Kpts/TP.204/1/97 tanggal 21 Januari 1997 (Natalina S.,
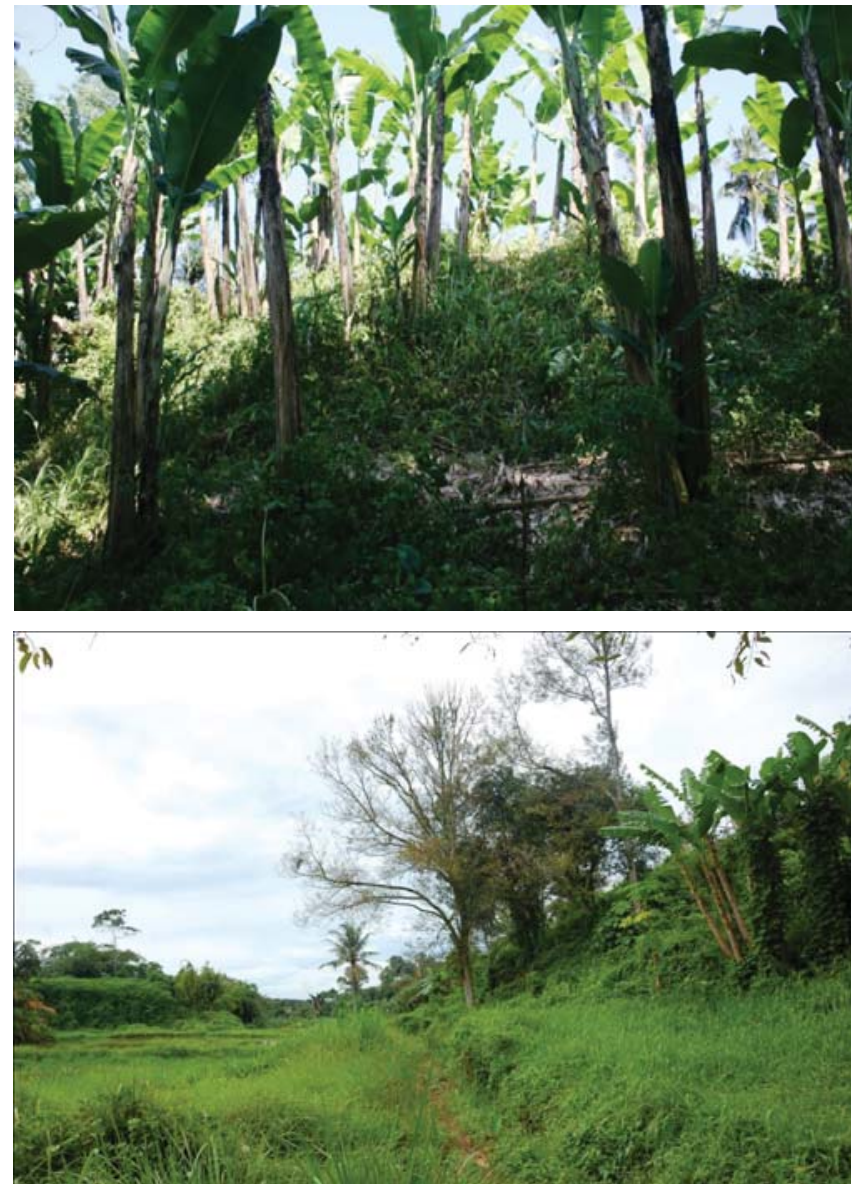

Gambar 3. Kebun pisang barangan milik warga di salah satu gundukan tanah pada bagian benteng tanah (atas) dan tebing teras Sungai Deli bagian dari benteng tanah di sektor II situs Benteng Puteri Hijau (bawah) (sumber: dok. Balar Medan, 2009; Setiawan, 2011)

2009; BPPT Sumut 2008)

Kebun pisang barangan yang terdapat di sekitar lokasi situs, sebagian besar berada di sektor II (lihat Gambar 2) status kepemilikan lahannya dimiliki oleh warga sekitarnya. Salah seorang warga pemilik kebun pisang, Surya Ginting, 45 tahun mengatakan:

"Kebun yang kami tanami dengan pohon pisang barangan dan tanaman lainnya merupakan warisan dari orang tua kami. Tanaman jenis pisang barangan sengaja dipilih karena daun dan buabnya bernilai ekonomi tinggi. Selain itu, tanaman pisang dan tanaman lainnya yang kami tanam di tanab yang menggunduk dapat mencegah runtuban tanah pada bagian tanah yang miring ketika turun bujan. Karena bila tanah gundukan runtub, maka luasan kebun kami akan semakin berkurang. Luasan kebun pisang keluarga kami sekitar dua rante (satu rante $=20 m \times 20$ m). Akan tetapi, ada juga warga yang hanya memiliki kebun pisang barangan yang luasnya tidak sebesar milik kami, karena tanahnya telah tergerus oleh air hujan."

Tanaman pisang barangan dan tanaman lainnya 
yang ditanam pada struktur benteng tanah dilakukan untuk mencegah longsornya gundukan tanah benteng akibat hujan (Gambar 3) yang dapat mengurangi luasan kebun milik keluarganya. Di samping itu, pada gundukan benteng tanah tersebut juga dibiarkan tumbuh tanaman ilalang, rerumputan, dan tanaman keras tahunan seperti durian, kelapa, cokelat, duku, mangga, jambe, beringin, dan jenis pohon keras lainnya.

Berdasarkan penuturan kepala dusun dan kepala desa setempat, keberadaan tanaman di lokasi struktur benteng tanah merupakan media dan metode untuk menjaga agar tanah yang miring tidak tererosi ketika turun hujan. Selain itu, keberadaan tanaman-tanaman tersebut juga untuk menjaga kejernihan mata air yang terdapat di beberapa bagian di luar struktur benteng tanah, salah satunya terletak di lokasi pancuran gading dekat sektor III (lihat Gambar 2) yang dianggap keramat oleh masyarakat sekitar lokasi situs. Adapun keberadaan pohon pisang barangan dan tanaman keras lain yang ditanam berdampingan berfungsi sebagai perindang, penahan longsor tanah, dan penahan air hujan yang jatuh agar tidak langsung mengikis tanah benteng. Adapun alasan utama mencampurkan jenis tanaman keras dengan tanaman pisang barangan menurut keduanya adalah upaya pemberdayaan lahan kebun secara efektif.

Menurut Balas Munthe, 60 tahun, pancuran gading sebagai mata air yang keluar dari bagian bawah struktur benteng tanah di sisi luarnya, belum pernah kering dan kejernihan airnya lebih baik daripada kualitas air mineral kemasan botol. Beberapa pohon pisang barangan ditanam di bagian atas pancuran gading, sedangkan beberapa lainnya ditanam di bagian bawah pancuran yang berbatasan dengan kolam warga. Pancuran gading merupakan lokasi

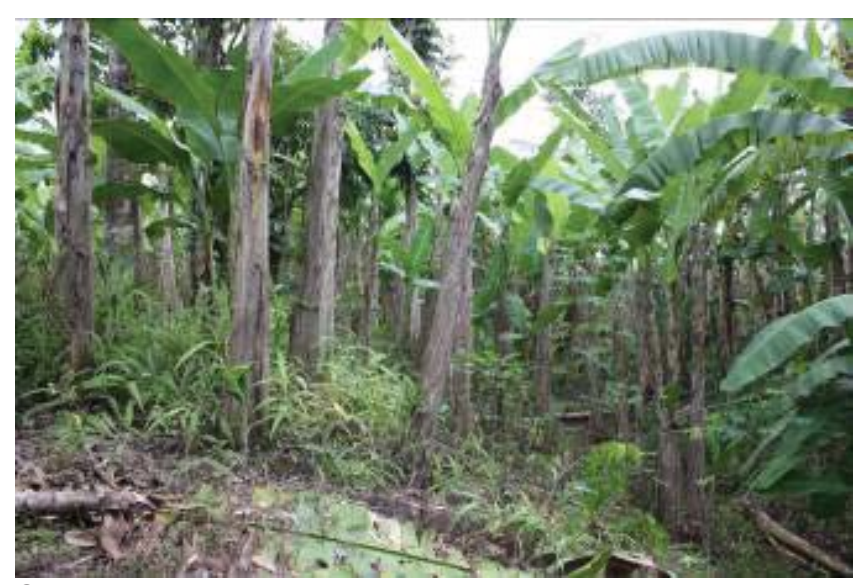

Gambar 4. Kebun pisang barangan warga di bagian lereng tanah di situs Benteng Puteri Hijau (sumber: dok. Tim penelitian 2009)
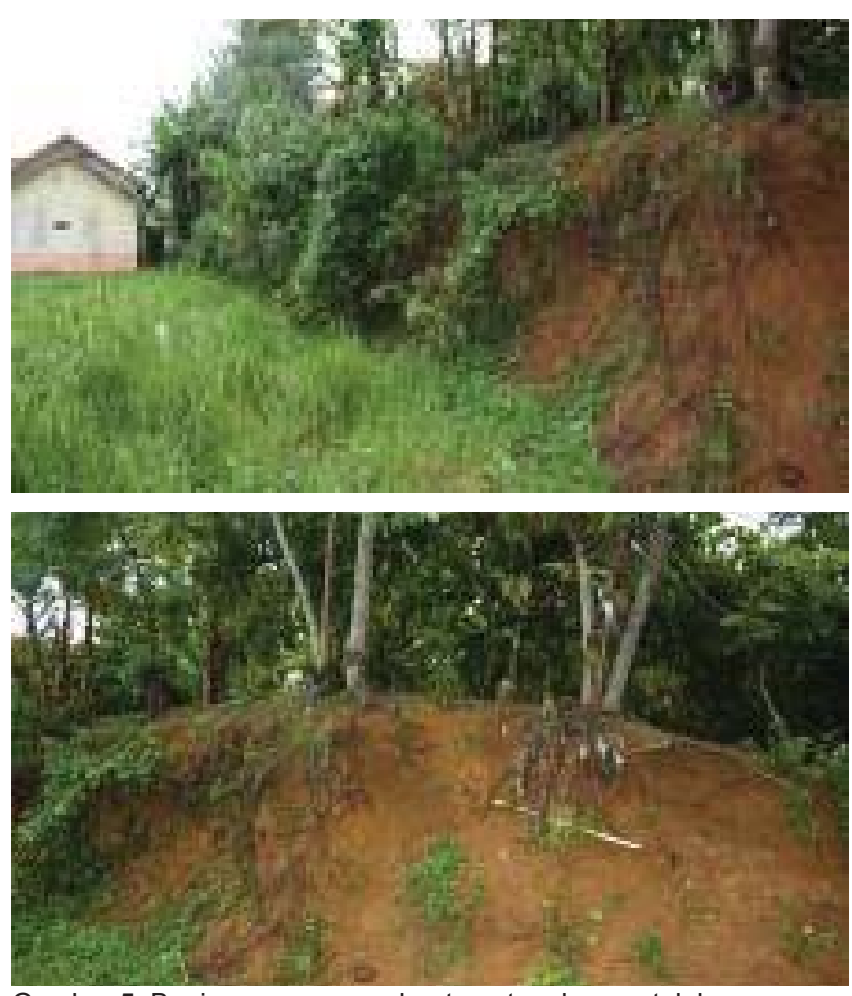

Gambar 5. Bagian penampang benteng tanah yang telah mengalami erosi (sumber: dok. BPCB Aceh Besar)

mata air yang dikaitkan dengan mitos keberadaan situs BPH ini dianggap sebagai bagian yang paling sakral oleh penduduk setempat maupun peziarah yang datang ke lokasi situs BPH. Tanaman pisang barangan tidak hanya ditanam di sekitar gundukan benteng tanah saja, tetapi di bagian dalam areal benteng tanah.

\section{Konservasi Tanah}

Berkenaan dengan permasalahan yang diajukan dalam penelitian ini, terlebih dahulu akan diuraikan mengenai metode konservasi bahan material pembentuk struktur bentengnya, yaitu tanah. Konservasi material terhadap struktur benteng yang berbahan baku tanah dengan cakupan areal yang sangat luas menggunakan metode umum konservasi tanah. Upaya konservasi material benteng tanah yang memiliki kemiringan curam adalah dengan cara mengkonservasi tanah pada bagian gundukan untuk mencegah terjadinya erosi.

Secara umum struktur tanah di benteng tanah situs $\mathrm{BPH}$ bertopografi miring dengan rata-rata kemiringan di atas $45^{\circ}$ (lihat Gambar 6). Hal tersebut memungkinkan rawannya erosi tanah pada struktur benteng tanah tersebut. Menurut Sumarno, erosi tanah adalah peristiwa terangkutnya tanah dari satu tempat ke tempat lain oleh air atau angin. Pada dasarnya ada 


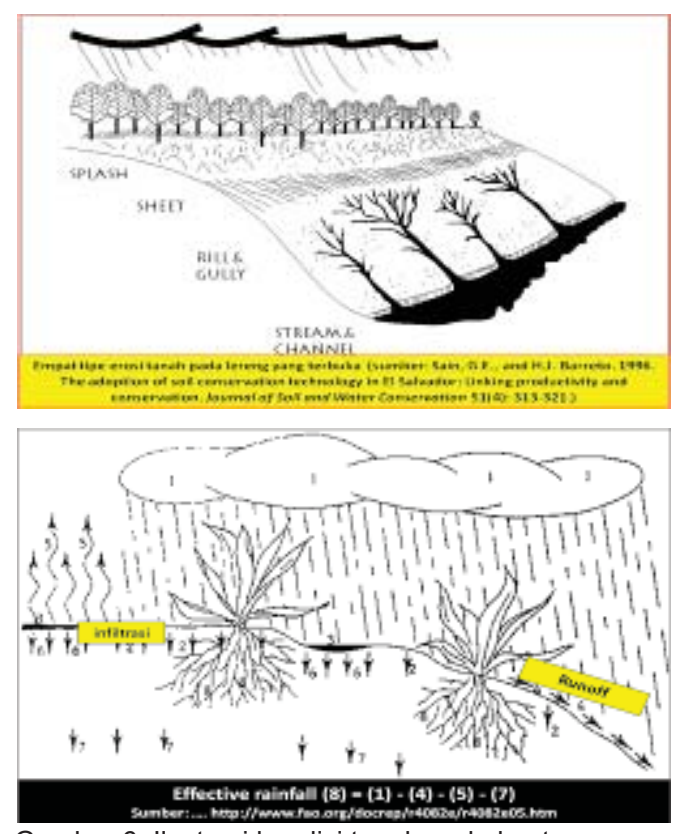

Gambar 6. Ilustrasi kondisi tanah pada kontur curam yang dapat menimbulkan erosi bila tidak ada vegetasi yang menutup tanahnya (sumber: Sumarno, 2013)

tiga proses penyebab erosi yaitu pelepasan partikel tanah, pengangkutan, dan pengendapan. Erosi menyebabkan hilangnya tanah lapisan atas dan unsur hara yang sangat penting bagi pertumbuhan tanaman. Tanah-tanah di daerah dengan kemiringan tanah di atas $45^{\circ}$ mempunyai risiko tererosi yang lebih besar daripada tanah di daerah datar. Selain tidak stabil akibat pengaruh kemiringan, air hujan yang jatuh akan terus menerus memukul permukaan tanah sehingga memperbesar risiko erosi (Sumarno, 2013: 1 dan 3).

Menurut Sumarno (2013: 5) Konservasi tanah adalah penempatan tiap bidang tanah pada cara penggunaan yang sesuai dengan kemampuan tanah dan memperlakukannya sesuai dengan syarat-syarat yang diperlukan agar tidak terjadi kerusakan tanah. Secara umum, tujuan konservasi tanah adalah meningkatkan produktivitas lahan secara maksimal, memperbaiki lahan yang rusak/kritis, dan melakukan upaya pencegahan kerusakan tanah akibat erosi. Sasaran konservasi tanah meliputi keseluruhan sumber daya lahan, yang mencakup kelestarian produktivitas tanah dalam meningkatkan kesejahteraan rakyat dan mendukung keseimbangan ekosistem.

Pada dasarnya teknik konservasi tanah dibedakan menjadi tiga yaitu: vegetatif, mekanik, dan kimia. Teknik konservasi tanah secara vegetatif memiliki beberapa keunggulan bila dibandingkan dengan teknik konservasi tanah secara mekanis maupun kimia. Hal tersebut antara lain karena penerapannya relatif mudah, biaya yang dibutuhkan relatif murah, mampu menyediakan tambahan hara bagi tanaman, menghasilkan hijauan pakan ternak, kayu, buah maupun hasil tanaman lainnya. Konservasi tanah secara vegetatif sejatinya merupakan segala bentuk pemanfaatan tanaman ataupun sisa-sisa tanaman untuk mengurangi erosi. Tanaman ataupun sisasisa tanaman berfungsi sebagai pelindung tanah terhadap daya pukulan butir air hujan maupun terhadap daya angkut air aliran permukaan (runoff), serta meningkatkan peresapan air ke dalam tanah. Tanah dengan penutup tanah yang baik berupa vegetasi akan memperkecil erosi dan limpasan permukaan (Sumarno, 2013: 6).

\section{Penanaman Pisang Barangan dan Konservasi Struktur Benteng Tanah}

Kebun campuran (sistem tumpang sari) yang dikelola dengan baik dapat menciptakan sistem multistrata yang dapat menurunkan kecepatan luncuran air hujan yang jatuh ke tanah. Oleh karena itu, penanaman pohon pelindung perlu dipertahankan karena dapat berfungsi sebagai tanaman konservasi tanah (Dariah, Tuherkih, dan Rachman, 2007). Tanaman pisang barangan yang ditanam oleh masyarakat setempat dengan sistem kebun campuran pada struktur benteng tanah di situs BPH dapat dikatakan sebagai bentuk konservasi tanah dalam upaya pencegahan erosi.

Penanaman pisang barangan dengan cara tumpang sari dengan tanaman lainnya pada struktur benteng tanah di situs BPH memiliki relevansi terhadap upaya konservasi tanah sebagai bahan dasar pembuatan struktur benteng tanah di situs Benteng Puteri Hijau. Hal tersebut tercermin pada pemilihan masyarakat setempat terhadap jenis tanaman yang ditanam. Pohon pisang barangan memiliki karakteristik yang lebih unggul dalam hal konservasi tanah bila dibandingkan dengan jenis tanaman pisang lainnya, yaitu ketebalan dan kekuatan daun, serta bidang penampang daun yang lebih luas.

Ketebalan dan kekuatan daun pisang barangan berpengaruh terhadap kekuatan daun pisang tersebut dalam menahan laju kecepatan air hujan yang akan mengenai permukaan bidang tanah di struktur benteng tanah yang miring, sehingga kecepatan laju air hujan yang akan mengenai permukaan struktur benteng tanah 
akan jauh berkurang. Adapun fungsi tumbuhan lainnya yang melingkupi seluruh permukaan struktur benteng tanah berfungsi sebagai penahan laju air hujan yang telah mengenai daun pisang, sebelum jatuh hingga permukaan tanah. Di samping itu, daun pisang memiliki bentuk morfologi daun yang ditunjang oleh keberadaan tulang daunnya yang berbentuk seperti saluran air yang dapat berfungsi sebagai jalan air yang memasukkan air ke dalam bilik tunas daun di bagian atas pohon pisang, sebelum air hujan jatuh ke tanah. Hal-hal tersebut menjadikan tanaman pisang, khususnya jenis pisang barangan dipilih oleh masyarakat di sekitar situs BPH sebagai jenis tanaman yang mampu menahan dan menjaga struktur benteng tanah tidak tererosi.

Adapun bidang penampang daun yang lebih luas bila dibandingkan dengan jenis tanaman pisang lainnya berpengaruh terhadap cakupan luas bidang tanah yang akan dilindungi dari benturan air hujan yang akan mengenai permukaan tanah pada struktur benteng tanahnya. Selain memiliki akar serabut yang mampu menahan material struktur tanah, daun pada pohon pisang bila dilihat dari atas akan seperti lingkaran pelindung tanah dengan ruasruas tulang daun sebagai saluran airnya. Pohon pisang juga termasuk tanaman yang sangat banyak mengandung air dalam tubuhnya, sehingga kemampuan menyimpan air dalam tubuh tanaman cukup baik.

Berdasarkan uraian tersebut, dapat diketahui relasi antara penanaman pisang barangan dengan cara tumpang sari dengan tanaman lainnya, khususnya kelompok tanaman ilalang dan rumputan yang berada di bawah pohon pisang barangan pada permukaan struktur benteng tanah di situs Benteng Puteri Hijau yang turut melindungi struktur benteng tanah dari erosi. Aktivitas masyarakat di sekitar situs Benteng Puteri Hijau yang melakukan penanaman pohon pisang barangan dan tanaman lainnya, serta membiarkan bagian permukaan benteng tanah tertutup rimbunan tanaman menjalar lainnya merupakan suatu wujud upaya konservasi terhadap struktur benteng berbahan tanah. Secara teknis, aktivitas mereka tersebut termasuk dalam upaya konservasi vegetatif seperti yang diungkapkan oleh Sumarno (2013).

Konservasi benteng tanah tersebut sebenarnya merupakan aktivitas perlindungan terhadap keawetan

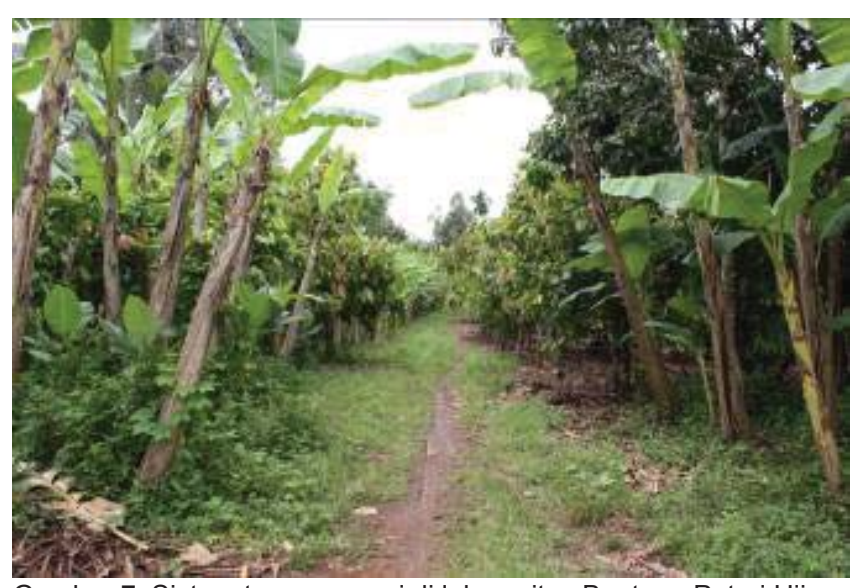

Gambar 7. Sistem tumpang sari di lahan situs Benteng Puteri Hijau (sumber: dok. BPCB Aceh Besar)

bentuk struktur benteng tanah agar tetap seperti sediakala pada saat awal mereka miliki dan manfaatkan. Adapun upaya tersebut sebenarnya dilandasi oleh rasa hormat mereka terhadap tokoh Puteri Hijau, yang dianggap sebagai leluhur mereka. Masyarakat yang berdomisili di dalam areal situs, tidak ingin merubah bentuk lahan yang telah lama mereka tinggali, sebagai bentuk penghormatan terhadap Tokoh Puteri Hijau yang sering mereka panggil dengan sebutan "Nenek". Sebagai upaya mempertahankan bentuk lahan warisan Nenek Puteri Hijau tersebut adalah dengan menanam pohon pisang barangan dengan cara tumpang sari.

Upaya masyarakat tersebut merupakan bagian dari melindungi tanah kebun mereka dari erosi dan menjaga ketersediaan air jernih, di samping sebagai penopang ekonominya. Penggunaan dan permintaan terhadap daun pisang barangan sebagai bahan pembungkus barang dagangan dalam transaksi jual-beli di pasar tradisional menjadi magnet utama menanam pohon pisang tersebut. Kondisi tersebut didukung oleh permintaan akan pisang barangan yang menjadi komoditas unggulan dari sekitaran Kota Medan, khususnya daerah Deli Serdang dan Sumatera Utara pada umumnya.

Kondisi umum penggunaan daun pisang sebagai bahan pembungkus, serta nilai jual tinggi pisang barangan disikapi oleh masyarakat yang memiliki kebun di sekitar benteng tanah di situs Benteng Puteri Hijau dengan menanami struktur benteng tanah dengan tanaman pisang barangan. Menilik apa yang telah diungkapkan oleh Koestoro (2010) di atas, bentuk kearifan lokal yang terdapat di situs Benteng Puteri Hijau, selain benteng tanahnya sendiri, adalah bentuk upaya konservasi material struktur benteng 
tanahnya. Caranya adalah dengan menanam pohon pisang barangan yang ditumpangsarikan dengan tanaman lain. Hal tersebut dapat dikatakan sebagai salah satu bentuk upaya konservasi vegetatif berbasis kearifan lokal untuk melindungi benteng tanah dari erosi.

\section{Penutup}

\section{Kesimpulan}

Bentuk konservasi material dengan menggunakan pohon pisang barangan yang ditanam secara tumpang sari dengan ilalang dan rumputan pada struktur benteng tanah di situs BPH dapat dikatakan sebagai aktivitas konservasi material berbasis kearifan lokal. Penanaman pohon pisang barangan yang dipilih oleh masyarakat di sekitar situs dalam upaya konservasi tanah pada struktur benteng tanahnya dilakukan karena pohon pisang barangan dianggap memiliki keunggulan pada kekuatan dan ketebalan daun serta luasan penampang daun yang lebih unggul dibandingkan dengan jenis tanaman pisang lainnya. Adapun inti dari keseluruhan aktivitas tersebut bertujuan untuk melindungi tanah dari erosi, menjaga ketersediaan air jernih, serta bentuk penghormatan kepada tokoh Puteri Hijau. Aktivitas tersebut dapat dikategorikan dalam konservasi vegetatif dalam ranah kajian ilmu tanah dan ilmu pertanian.

Upaya tersebut, selain secara teknis mengkonservasi benteng tanahnya, juga dapat memberikan dampak pada usaha peningkatan pendapatan ekonomi warga di sekitar tinggalan masa

\section{Daftar Pustaka}

BP3 Banda Aceh, 2008. Laporan Penggalian Penyelamatan Situs Benteng Putri Hijau Desa Deli Tua, Kecamatan Namorambe, Kabupaten Deli Serdang, Provinsi Sumatera Utara. Departemen Kebudayaan dan Pariwisata: Direktorat Jenderal Sejarah dan Purbakala.

BPTP, Sumatera Utara. 2008. Teknologi Penanaman Pisang Barangan Sistem Dua Jalur (Doble Raw). Dalam http://pustak.a.litbang.deptan.go.id/agritek/ smut0908.pdf. Diunduh 21 Juli 2014, Pukul 22.30 WIB. lalu tersebut. Konservasi berbasis kearifan lokal yang dilakukan masyarakat di sekitar situs Benteng Puteri Hijau dapat dikatakan sebagai bentuk pemanfaatan tinggalan masa lalu yang berbasis perlindungan terhadap tinggalan tersebut.

\section{Rekomendasi}

Bentuk praktik konservasi berbasis kearifan lokal dalam bentuk pembudidayaan tanaman bernilai ekonomi tinggi dapat dikembangkan potensinya. Selain ikut menjaga dan melindungi objek budaya material tinggalan masa lalu, juga memberikan potensi pengembangan ekonomi bagi masyarakatnya. Hal ini memungkinkan kelak akan lebih menyentuh kepentingan peningkatan kesejahteraan masyarakat yang hidup di sekitar tinggalan masa lalu untuk menjaga, melindungi, sekaligus terhidupi oleh tinggalan masa lalu yang ada disekitarnya. Konsep ini memungkinkan adanya pemberdayaan masyarakat secara simultan dan berkelanjutan dalam kerangka pemanfaatan cagar budaya, tanpa melupakan aspek pelestariannya sebagai komponen utamanya. Satu hal yang perlu diingat, bahwa konservasi berbasis kearifan lokal tidak dapat berjalan sendiri dalam kerangka besar pelestarian situs tersebut. Konservasi berbasis kearifan lokal tidak akan ada artinya bila tidak didukung oleh upaya konservasi teknis perlindungan situs, misalnya: pembuatan batas yang tegas dan jelas terhadap zonasi situs (inti, penyangga, pengembangan), serta penetapan dan pengangkatan juru pelihara situs.

Biornstad, Margareta. 1990. "The ICOMOS Internastional Committee on Archaelogical Management (ICAHM)". dalam Henry F. Cleere (Ed.). Archaeological Heritage Management in The Modern World. UnwimHyman. London. Hlm. 70-78.

Dariah, Ai., Enggis Tuherkih, Achmad Rachman. 2007. “Teknologi Pemupukan Spesifik Lokasi dan Konservasi Tanah, Desa Talun Kenas, Kecamatan STM Hilir, Kab. Deliserdang”. Bogor: Balai Penelitian Tanah. Dalam http:// 
pustaka.litbang.deptan.go.id/agritek/smut0908.pdf. Diunduh 21 Juli 2014, Pukul 21.30 WIB.

Koestoro, Lucas P. 2010. "Benteng dan Kearifan Lokal", dalam Seri warisan Sumatera Bagian Utara No.0510. Medan: Balai Arkeologi Medan. hlm 96 -- 133.

Natalina S., Fransiska. 2009. "Analisis Komparasi Usahatani Pisang Barangan Antara Sistem Konvensional dengan Sistem Dobel Raw". Skripsi. Medan: Departemen Sosial Ekonomi Pertanian, Fakultas Pertanian, Universitas Sumatera Utara. Dalam http://repository. usu.ac.id/bitstream/123456789/7497/1/0 9E01511.pdf. Diunduh 21 Juli 2014, Pukul 20.45 WIB.

Setiawan, Taufiqurrahman, dkk. 2011. Penelitian Situs Dunia Di Sumatera Utara Benteng Puteri Hijau. Medan: Dinas Kebudayaan dan Pariwisata, Museum Negeri Provinsi Sumatera Utara.
Sumarno, 2013. "Vegetasi Untuk Konservasi Tanah dan Air". Dalam bttp://marno.lecture.ub.ac. id/files/2013/11/VEGETASI-untukKONSERVASI-TANAH-DAN-AIR.docx. Diunduh 21 Juli 2014, Pukul 20.30 WIB.

Tim Peneliti, 2009. Laporan Penelitian Komprehensif Pada Situs Yang Diduga Sebagai Benteng Putri Hijau di Desa Delitua, Kecamatan Namorambe, Kabupaten Deli Serdang. Laporan Penelitian. Lubukpakam: Dinas Kebudayaan dan Pariwisata Kabupaten Deli Serdang. 